WARSZTATY Z GEOGRAFII TURYZMU

ISBN 978-83-7969-262-0 $\quad$ s. 255-277

http://dx.doi.org/10.18778/7969-262-0.17

Bogdan WŁODARCZYK

Uniwersytet Łódzki

\title{
BAZA NOCLEGOWA ŁODZI I REGIONU ŁÓDZKIEGO NA POCZĄTKU DRUGIEJ DEKADY XXI WIEKU
}

\section{Wstęp}

Baza noclegowa stanowi jeden z ważniejszych elementów zagospodarowania turystycznego obszaru, a tym samym jest częścią jego szeroko rozumianego potencjału turystycznego (KACZMAREK, STASIAK, WŁODARCZYK 2010, KOWALCZYK, DEREK 2010). Ze względu na lokalizację, historię i architekturę budynków, w których znajdują się miejsca noclegowe, można je traktować także jako swoistą atrakcję turystyczną. Oryginalne hotele stają się powodem podejmowania, czasem bardzo odległych, podróży turystycznych (MILEWSKA, WŁODARCZYK 2009). Hotelarstwo to także bardzo ważna gałąź gospodarki turystycznej miejscowości, regionów czy kontynentów (KOWALCZYK 2001, MATCZAK 2004), dlatego też aktualne badania i analizy powinny być wykorzystywane w celach planistycznych i prognostycznych. Znajomość trendów związanych z rozwojem poszczególnych branż gospodarki turystycznej jest niezbędna $\mathrm{w}$ celu zapewnienia jej prawidłowego funkcjonowania.

Koniec pierwszej dekady XXI w. był okresem widocznego kryzysu w branży hotelarskiej, który wyraźnie odbił się na całej gospodarce turystycznej świata i jego regionów. Przejawiało się to głównie w zahamowaniu budowy nowych inwestycji hotelarskich oraz zmniejszaniu stopnia wykorzystania pokoi i miejsc noclegowych. Początek drugiej dekady to niewielki, 
ale zauważalny wzrost liczby obiektów i miejsc noclegowych. Tendencje te dotyczą także bazy hotelarskiej w Polsce rozpatrywanej na poziomie całego kraju oraz regionalnym i lokalnym.

W opracowaniu podjęto próbę pokazania aktualnego stanu hotelarstwa w regionie łódzkim, który na tle rozwoju zjawiska w Polsce i Europie charakteryzuje się przeciętnym poziomem rozwoju bazy noclegowej. $\mathrm{W}$ analizach bazy noclegowej rozpatrywane będą nie tylko liczba i struktura obiektów czy liczba miejsc, ale także poziom nasycenia rynku hotelarskiego oraz poziom wykorzystania miejsc noclegowych.

Podstawowym materiałem analitycznym wykorzystanym w opracowaniu są dane statystyczne opublikowane przez Główny Urząd Statystyczny (Turystyka w 2012 r. 2013) oraz Urząd Statystyczny w Łodzi (Turystyka w województwie łódzkim w 2012 r., Wojezoództwo łódzkie - podregiony, powiaty, gminy 2013). Informacje te zostały uzupełnione danymi opublikowanymi przez Eurostat oraz własnymi obserwacjami (badaniami) autora.

Według GUS baza noclegowa turystyki obejmuje turystyczne obiekty noclegowe (hotelarskie), w skład których wchodzą:

- obiekty hotelowe (hotele, motele, pensjonaty oraz inne obiekty, w których świadczone są usługi o podobnym standardzie, np. zajazdy, goścince);

- inne obiekty, w których świadczone są usługi noclegowe, ale nie spełniają wymogów przewidzianych przepisami dla tych, które wyróżniono w ustawie O ustugach turystycznych z 1997 r. (ze zm.); w ich skład wchodzą m.in. domy studenckie, internaty, hostele, ośrodki do wypoczynku sobotnio-niedzielnego i świątecznego, ośrodki sportowo-rekreacyjne, ośrodki kolonijne oraz zakłady uzdrowiskowe.

GUS w informacjach o obiektach i miejscach noclegowych nie uwzględnia placówek nieczynnych z powodu przebudowy lub remontu. Do roku 2010 w statystykach nie uwzględniano także pokoi gościnnych i kwater agroturystycznych. Od 2012 r. informacje te są publikowane, a pokoje gościnne i kwatery agroturystyczne wykazywane są w strukturze bazy noclegowej jako obiekty zakwaterowania indywidualnego. W przypadkach, kiedy wyraźnie nie określono struktury miejsc noclegowych analizy dotyczą miejsc całorocznych i sezonowych łącznie.

Jako stopień wykorzystania (obłożenie, frekwencja) miejsc noclegowych (lub pokoi) w niniejszym opracowaniu rozumie się stosunek liczby udzielonych noclegów (lub wynajętych pokoi) w danym okresie do nominalnej liczby miejsc noclegowych (pokoi) w tym okresie. Nominalna liczba miejsc noc- 
legowych (pokoi) to suma miejsc noclegowych (pokoi) przygotowanych dla gości w każdym dniu działalności obiektu w badanym przedziale czasowym (MILEWSKA, SKRZYPCZYŃSKI, WŁODARCZYK 2004).

\section{Polskie hotelarstwo na tle wybranych państw europejskich}

W porównaniu z innymi krajami europejskimi polskie hotelarstwo nie wygląda nadal najlepiej. Dotyczy to zarówno poziomu nasycenia rynku hotelowego, jak i poziomu obłożenia pokoi hotelowych. W przypadku pierwszej cechy (poziom nasycenia obiektami hotelowymi) na 34 przebadane rynki ho-

\begin{tabular}{|c|c|c|c|c|}
\hline Macedonia & ${ }^{2}, 1$ & & & \\
\hline Polska & 3,2 & & & \\
\hline Serbia & $\square, 5$ & & & \\
\hline Litwa & 4,5 & & & \\
\hline Rumunia & $\Longrightarrow 5$ & & & \\
\hline Belgia & 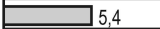 & & & \\
\hline Lotwa & 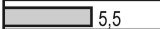 & & & \\
\hline Holandia & 6,3 & & & \\
\hline Wegry & ב 6,7 & & & \\
\hline Slowacja & 7,2 & & & \\
\hline Dania & 7,7 & & & \\
\hline Francja & 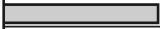 & 9,5 & & \\
\hline Wielka Brytania & & 10,2 & & \\
\hline Finlandia & & 10,5 & & \\
\hline Slowenia & & 10,7 & & \\
\hline Czechy & $\bar{~}$ & 11,3 & & \\
\hline Niemcy & בe & 11,3 & & \\
\hline Estonia & 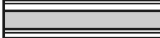 & 11,7 & & \\
\hline Szwecja & ב" & 11,8 & & \\
\hline UE & 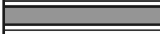 & 12,3 & & \\
\hline Portugalia & $\bar{~}$ & 12,5 & & \\
\hline Irlandia & ב & 15 & & \\
\hline Luksemburg & ב" & 15,2 & & \\
\hline Norwegia & 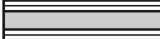 & 16,3 & & \\
\hline Bulgaria & ב & 16,5 & & \\
\hline Chorwacja & 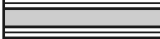 & 17 & & \\
\hline Lichtenstein & ב" & 17 & & \\
\hline Szwajcaria & & $\Longrightarrow 17$, & & \\
\hline Wlochy & 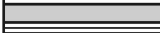 & 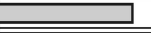 & 18,4 & \\
\hline Hiszpania & & & 19,9 & \\
\hline Islandia & & & 30,6 & \\
\hline Austria & & & 34,4 & \\
\hline Grecja & & & 35,2 & \\
\hline Malta & & & & 42,2 \\
\hline Cypr & & & & $\begin{array}{ll}48.1 \\
\end{array}$ \\
\hline & $0 \quad$ Liczba pc & $\begin{array}{l}0 \\
\text { koi w obiektacl }\end{array}$ & $\begin{array}{l}0 \\
\text { typu hotelowego na } 1000 \mathrm{~m}\end{array}$ & zkańców 50 \\
\hline
\end{tabular}

Rys. 1. Nasycenie rynku hotelowego w Polsce w roku na tle wybranych krajów europejskich Źródło: opracowanie własne na podstawie sprawozdawczości Eurostat i GUS (2012) 
telarskie zajmujemy dopiero 33. miejsce, z wartością 3,2 pokoju hotelowego na 100 mieszkańców (rys. 1). Dla porównania, średnia tego wskaźnika dla Unii Europejskiej wynosi 12,3, a kraje takie, jak Grecja, Malta czy Cypr, osiągają wartości powyżej 35,0.

Podobnie niesatysfakcjonująca jest sytuacja jeśli chodzi o poziom wykorzystania pokoi w obiektach hotelowych. W krajach takich, jak Francja, Holandia czy Malta, wskaźnik ten przekracza 60,0\%, a w Polsce jest nieznacznie wyższy niż poziom 40\% (w 2012 r. - 41,1\%) - rys. 2.

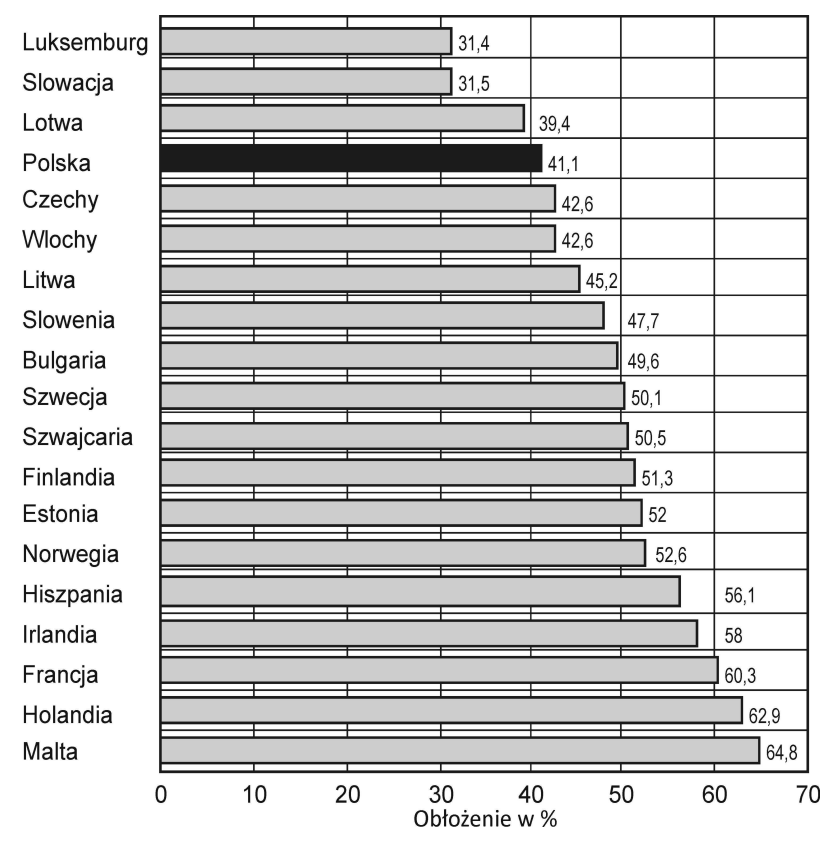

Rys. 2. Obłożenie hoteli w Polsce na tle wybranych krajów europejskich w roku 2012

Źródło: opracowanie własne na podstawie sprawozdawczości Eurostat i GUS (2012)

\section{Baza noclegowa w Polsce}

W Polsce w ostatnich latach zauważa się tendencje wzrostowe zarówno jeśli chodzi o liczbę obiektów, jak i liczbę pokoi czy miejsc noclegowych (tab. 1, rys. 3). Według danych GUS z połowy 2013 r., liczba obiektów wzrosła 
o 3,1\% w stosunku do roku 2012. Dynamika wzrostu liczby miejsc noclegowych była zdecydowanie mniejsza i wynosiła w analogicznym okresie zaledwie $0,6 \%$.

Tabela 1. Turystyczne obiekty noclegowe w 2013 roku (stan na 31 lipca 2013 r.)

\begin{tabular}{|c|c|c|c|c|c|c|}
\hline \multirow{3}{*}{ Wyszczególnienie } & \multicolumn{3}{|c|}{ Obiekty } & \multicolumn{3}{|c|}{ Miejsca noclegowe } \\
\hline & 2012 & \multicolumn{2}{|c|}{2013} & 2012 & \multicolumn{2}{|c|}{2013} \\
\hline & \multicolumn{2}{|c|}{$\begin{array}{c}\text { w liczbach } \\
\text { bezwzględnych }\end{array}$} & $\begin{array}{l}2012 \mathrm{r} . \\
=100\end{array}$ & \multicolumn{2}{|c|}{$\begin{array}{c}\text { w liczbach } \\
\text { bezwzględnych }\end{array}$} & $\begin{array}{r}2012 \mathrm{r} . \\
=100\end{array}$ \\
\hline Ogółem & 9483 & 9775 & 103,1 & 675433 & 679445 & 100,6 \\
\hline Obiekty hotelowe & 3414 & 3485 & 102,1 & 264145 & 274297 & 103,8 \\
\hline Hotele & 2014 & 2107 & 104,6 & 198093 & 208617 & 105,3 \\
\hline Motele & 116 & 116 & 100,0 & 4264 & 4359 & 102,2 \\
\hline Pensjonaty & 311 & 307 & 98,7 & 13714 & 13874 & 101,2 \\
\hline Inne obiekty hotelowe & 973 & 955 & 98,2 & 48074 & 47447 & 98,7 \\
\hline Pozostałe obiekty & 6069 & 6290 & 103,6 & 411288 & 405148 & 98,5 \\
\hline Domy wycieczkowe & 53 & 48 & 90,6 & 3918 & 3560 & 90,9 \\
\hline Schroniska & 61 & 60 & 98,4 & 3183 & 3041 & 95,5 \\
\hline Schroniska młodzieżowe & 44 & 45 & 102,3 & 2880 & 2809 & 97,5 \\
\hline Szkolne schroniska młodzieżowe & 282 & 274 & 97,2 & 17248 & 16655 & 96,6 \\
\hline Ośrodki wczasowe & 1079 & 1047 & 97,0 & 116395 & 111783 & 96,0 \\
\hline Ośrodki kolonijne & 92 & 99 & 107,6 & 13126 & 13389 & 102,0 \\
\hline Ośrodki szkoleniowo-wypoczynkowe & 450 & 432 & 96,0 & 46824 & 46280 & 98,8 \\
\hline Domy pracy twórczej & 37 & 34 & 91,9 & 1752 & 1708 & 97,5 \\
\hline Zespoły domków turystycznych & 388 & 394 & 101,5 & 24267 & 24234 & 99,9 \\
\hline Kempingi & 131 & 129 & 98,5 & 21868 & 20081 & 91,8 \\
\hline Pola biwakowe & 192 & 187 & 97,4 & 21401 & 21463 & 100,3 \\
\hline Hostele & 108 & 110 & 101,9 & 6924 & 7477 & 108,0 \\
\hline Zakłady uzdrowiskowe & 190 & 198 & 104,2 & 33681 & 34154 & 101,4 \\
\hline Pokoje gościnne & 1623 & 1823 & 112,3 & 37583 & 40459 & 107,7 \\
\hline Kwatery agroturystyczne & 683 & 800 & 117,1 & 11124 & 12771 & 114,8 \\
\hline Pozostałe obiekty niesklasyfikowane & 656 & 610 & 93,0 & 49114 & 45284 & 92,2 \\
\hline
\end{tabular}

Źródło: opracowanie własne na podstawie sprawozdawczości GUS (2013).

Największy wskaźnik wzrostu - 4,6\%, odnotowały hotele (w grupie obiektów hotelowych) oraz kwatery agroturystyczne $(17,1 \%)$ w grupie "pozostałe obiekty".

Dość dynamicznie rozwijającym się segmentem bazy noclegowej, stosunkowo młodym na polskim rynku hotelarskim, są hostele, których wskaźnik przyrostu miejsc noclegowych w sezonie 2012/2013 wyniósł 8,0. Popular- 
ność tego typu obiektów, klasyfikowanych między schroniskiem młodzieżowym a hotelem, wynika $\mathrm{z}$ bardzo dobrych relacji między ceną a oferowaną jakością usług. Jeszcze kilkanaście lat temu w Polsce formalnie nie było obiektów tego rodzaju. Obecnie jest to jeden z najbardziej dynamicznie rozwijających się segmentów rynku hotelowego.

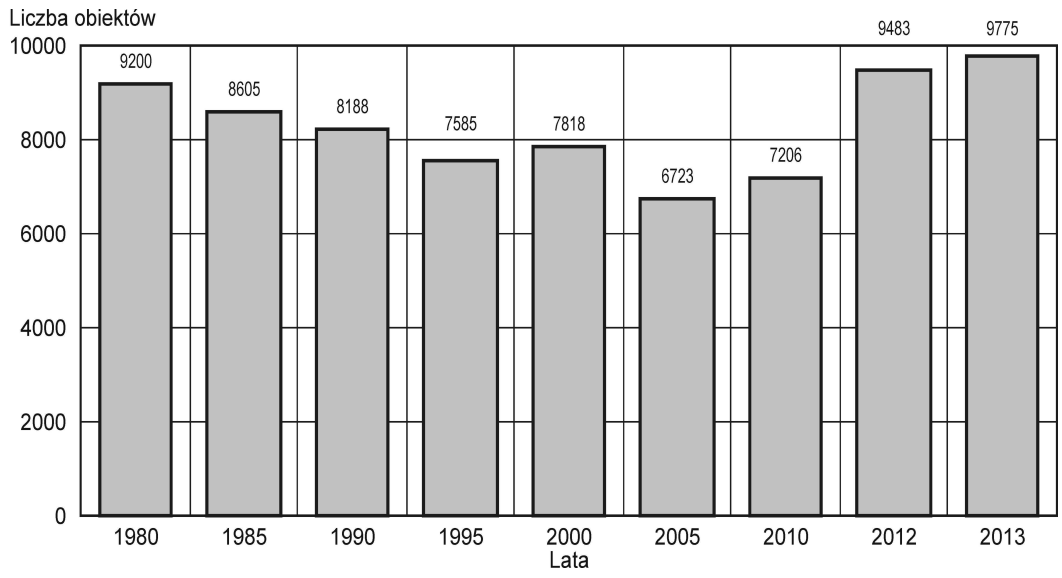

Rys. 3. Baza noclegowa w Polsce w latach 1980-2013

Źródło: opracowanie własne na podstawie sprawozdawczości GUS w latach 1980-2013

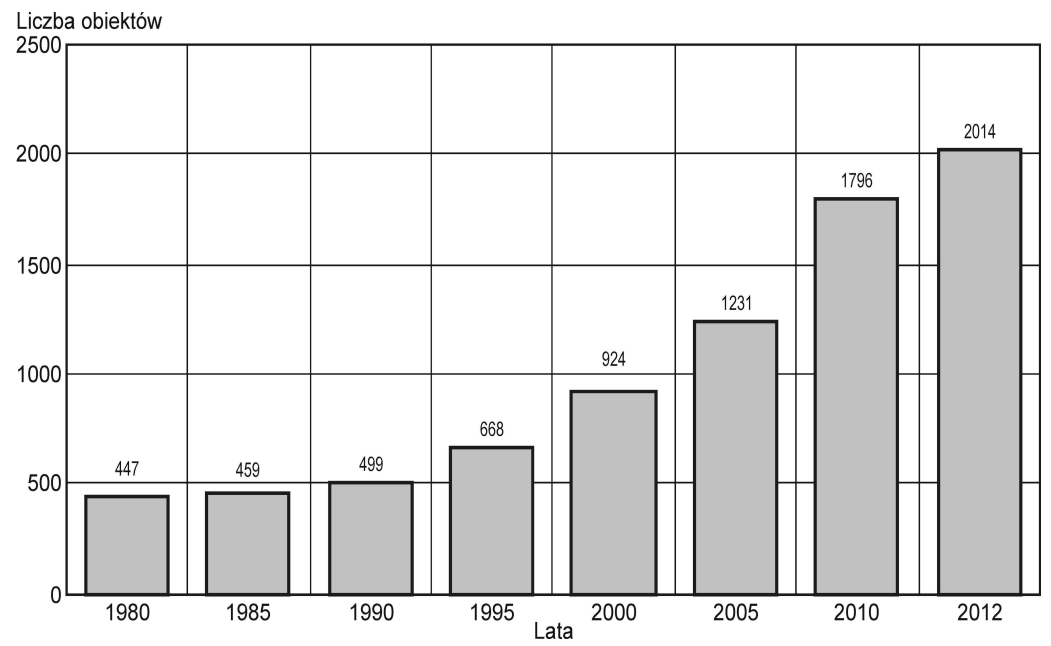

Rys. 4. Liczba hoteli w Polsce w latach 1980-2012

Źródło: opracowanie własne na podstawie sprawozdawczości GUS w latach 1980-2012 
W przypadku długookresowych trendów wyraźnie widać, że po załamaniu rynku hotelowego $w$ latach 2005-2010 (rys. 4) nastąpiło ożywienie zarówno pod względem wzrostu liczby obiektów, jak i miejsc noclegowych. Przy czym liczba obiektów wzrasta bardziej dynamicznie niż liczba miejsc.

Optymizmem napawa stały dynamiczny wzrost liczby hoteli. W roku 2012 ich liczba przekroczyła 2000, ale nadal jest to wartość niewystarczająca w stosunku do nasycenia rynku turystycznego w tego typu bazę noclegową. W strukturze obiektów hotelowych dominują hotele trzy- i dwugwiazdkowe (rys. 5, tab. 2), których udział wynosi 72,5\%. Zdecydowanie jest zbyt mało w stosunku do aktualnych potrzeb hoteli o najwyższej, pięciogwiazdkowej kategorii. Stanowią one jedynie 2,3\% wszystkich obiektów i występują tylko w 10 województwach naszego kraju (rys. 7).

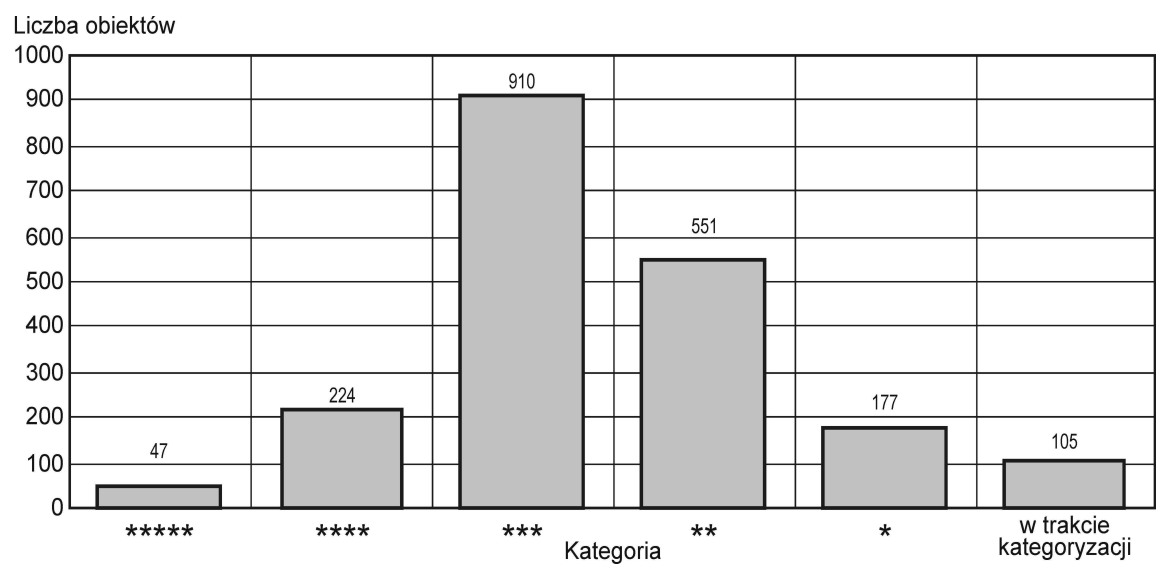

Rys. 5. Struktura hoteli w Polsce w roku 2012 według kategorii Źródło: opracowanie własne na podstawie sprawozdawczości GUS (2013)

Tabela 2. Stopień wykorzystania pokoi (w\%) według kategorii hotelu w Polsce w latach 1995-2012

\begin{tabular}{|l|c|c|c|c|c|}
\hline \multirow{2}{*}{$\begin{array}{c}\text { Kategoria } \\
\text { hotelu }\end{array}$} & \multicolumn{5}{|c|}{ Rok } \\
\cline { 2 - 6 } & 1995 & 2000 & 2005 & 2010 & 2012 \\
\hline Ogółem & 44,4 & 40,6 & 43,1 & 41,6 & 43,6 \\
\hline$* * * *$ & 62,6 & 58,9 & 52,1 & 58,8 & 63,4 \\
\hline$* * * *$ & 50,4 & 52,0 & 52,2 & 47,1 & 50,1 \\
\hline$* * *$ & 47,5 & 42,5 & 44,2 & 39,1 & 40,5 \\
\hline$* *$ & 40,4 & 36,9 & 39,3 & 38,3 & 38,1 \\
\hline$*$ & 33,4 & 29,9 & 39,1 & 41,9 & 40,5 \\
\hline
\end{tabular}

Źródło: opracowanie własne na podstawie sprawozdawczości GUS w latach 1995-2012. 
O potrzebie budowy nowych luksusowych hoteli świadczy poziom ich obłożenia, który jest wyraźnie wyższy niż w pozostałych kategoriach. W Polsce można zauważyć dość oryginalną tendencję jeśli chodzi o stopień wykorzystania pokoi hotelowych (tab. 2). W przeciwieństwie do krajów zachodnioeuropejskich, USA czy Kanady, w których wielkość obłożenia maleje wraz z kategorią hoteli, największe obłożenie (powyżej 50\%) mają hotele luksusowe $\left(^{* * * *}\right)$ i wysokiej klasy $\left({ }^{* * *}\right)$. Hotele średniej klasy $\left({ }^{* * *}\right)$ są wykorzystywane w $40-45 \%$, a ekonomiczne $\left(^{* *}\right)$ i budżetowe $\left(^{*}\right)$ rzadko powyżej $40 \%$.

Sezon największego wykorzystania pokoi w hotelach polskich trwa od maja do września, z niewielkim „,wypłaszczeniem” (por. rys. 6) w miesiącach wakacyjnych, kiedy to obłożenie oscyluje w granicach $50 \%$. Można więc zaryzykować stwierdzenie, że baza ta wykorzystywana jest w większym stopniu przy organizacji kongresów i konferencji (maj i wrzesień) oraz w celach wypoczynkowych (lipiec, sierpień), a w mniejszym w celach biznesowych. Podobna tendencja dotyczy także obiektów ogółem, z tym wszakże, że poziom wykorzystania pokoi we wszystkich rodzajach obiektów jest średnio od 3 do $5 \%$ niższy.

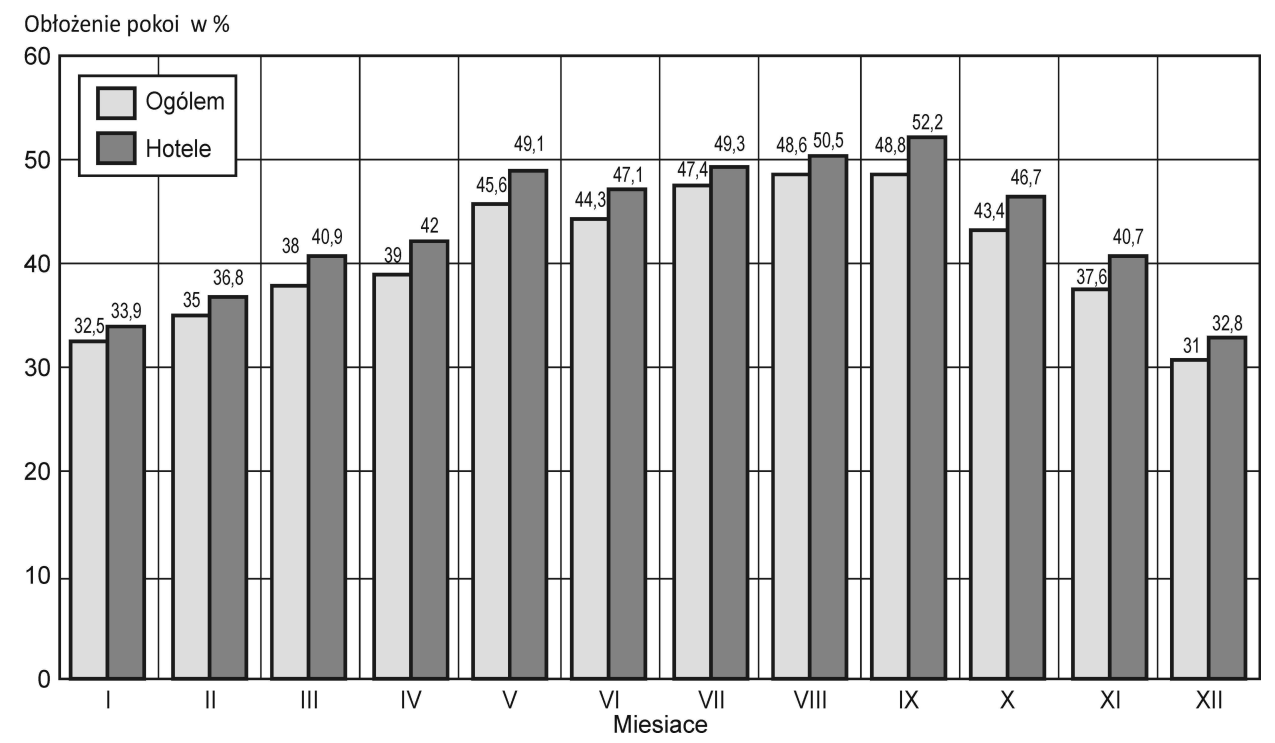

Rys. 6. Stopień wykorzystania pokoi w obiektach hotelowych w roku 2012 według miesięcy (w \%)

Źródło: opracowanie własne na podstawie sprawozdawczości GUS (2013) 
W ujęciu regionalnym największą liczbę obiektów noclegowych, a tym samym miejsc noclegowych, mogą poszczycić się województwa, które tradycyjnie uchodzą za atrakcyjne turystyczne (małopolskie, pomorskie i zachodniopomorskie), w których baza noclegowa liczy ponad 1200 obiektów i ponad 80 tys. miejsc noclegowych. Biorąc pod uwagę jedynie liczbę hoteli to w czołówce, oprócz małopolskiego, znajdą się jeszcze województwo dolnośląskie oraz wielkopolskie, w których liczba hoteli przekracza 200 (tab. 3).

Tabela 3. Obiekty noclegowe w Polsce według województw w roku 2012

\begin{tabular}{|c|c|c|c|c|c|c|c|c|c|c|}
\hline \multirow[b]{2}{*}{ Województwo } & \multicolumn{2}{|c|}{ Ogółem } & \multicolumn{2}{|c|}{ Hotele } & \multicolumn{2}{|c|}{ Motele } & \multicolumn{2}{|c|}{ Pensjonaty } & \multicolumn{2}{|c|}{ Pozostałe } \\
\hline & $\begin{array}{c}\text { liczba } \\
\text { obiek- } \\
\text { tów }\end{array}$ & $\begin{array}{l}\text { liczba } \\
\text { miejsc }\end{array}$ & 1.o. & 1.m. & 1.o. & 1.m. & 1.o. & 1.m. & 1.o. & l.m. \\
\hline Polska & 9483 & 675433 & 2014 & 198093 & 116 & 4264 & 311 & 13714 & 6069 & 411288 \\
\hline Dolnośląskie & 946 & 59072 & 218 & 22330 & 6 & 242 & 59 & 2390 & 569 & 28956 \\
\hline $\begin{array}{l}\text { Kujawsko- } \\
\text {-Pomorskie }\end{array}$ & 333 & 26559 & 94 & 7092 & 6 & 207 & 3 & 243 & 193 & 17658 \\
\hline Lubelskie & 336 & 19561 & 71 & 4711 & 12 & 256 & 14 & 596 & 206 & 12086 \\
\hline Lubuskie & 307 & 20505 & 66 & 4695 & 12 & 521 & 9 & 464 & 176 & 13084 \\
\hline Łódzkie & 373 & 23237 & 103 & 9963 & 8 & 341 & 3 & 76 & 163 & 9252 \\
\hline Małopolskie & 1400 & 84713 & 287 & 29696 & 14 & 293 & 60 & 3362 & 971 & 47712 \\
\hline Mazowieckie & 466 & 45764 & 173 & 27389 & 1 & 517 & 6 & 246 & 193 & 13665 \\
\hline Opolskie & 120 & 7873 & 36 & 1884 & 4 & 25 & 2 & 36 & 62 & 5152 \\
\hline Podkarpackie & 452 & 24205 & 105 & 6093 & 2 & 121 & 11 & 560 & 279 & 15537 \\
\hline Podlaskie & 243 & 12409 & 28 & 3164 & 4 & 115 & 7 & 210 & 167 & 7072 \\
\hline Pomorskie & 1275 & 92541 & 170 & 16674 & 4 & 155 & 38 & 1839 & 983 & 69575 \\
\hline Śląskie & 617 & 44155 & 169 & 17664 & 12 & 137 & 11 & 433 & 350 & 20620 \\
\hline Świętokrzyskie & 206 & 13157 & 73 & 5438 & 7 & 355 & 7 & 289 & 99 & 6597 \\
\hline $\begin{array}{l}\text { Warmińsko- } \\
\text {-Mazurskie }\end{array}$ & 487 & 39437 & 101 & 10699 & 4 & 89 & 27 & 871 & 297 & 24307 \\
\hline Wielkopolskie & 703 & 42278 & 216 & 16039 & 18 & 724 & 22 & 636 & 365 & 21097 \\
\hline $\begin{array}{l}\text { Zachodnio- } \\
\text { pomorskie }\end{array}$ & 1219 & 119967 & 104 & 14562 & 3 & 166 & 32 & 1463 & 997 & 98918 \\
\hline
\end{tabular}

Objaśnienia: 1.o. - liczba obiektów noclegowych, 1.m. - liczba miejsc noclegowych.

Źródło: opracowanie własne na podstawie sprawozdawczości GUS (2013).

W tym zestawieniu województwo łódzkie zamyka pierwszą dziesiątkę województw, co jest pozycją wysoce niezadowalającą w kontekście ambicji rozwoju turystyki, jaką wykazują władze regionu i stolicy województwa (tab. 3). Łódzkie jest jednym z pięciu województw w Polsce, które nie posiada ani jednego hotelu pięciogwiazdkowego (rys. 7). Potrzeba wybudo- 
wania w stolicy województwa takiego obiektu jest niezbędnym warunkiem budowania prestiżu oraz marki miasta i regionu.

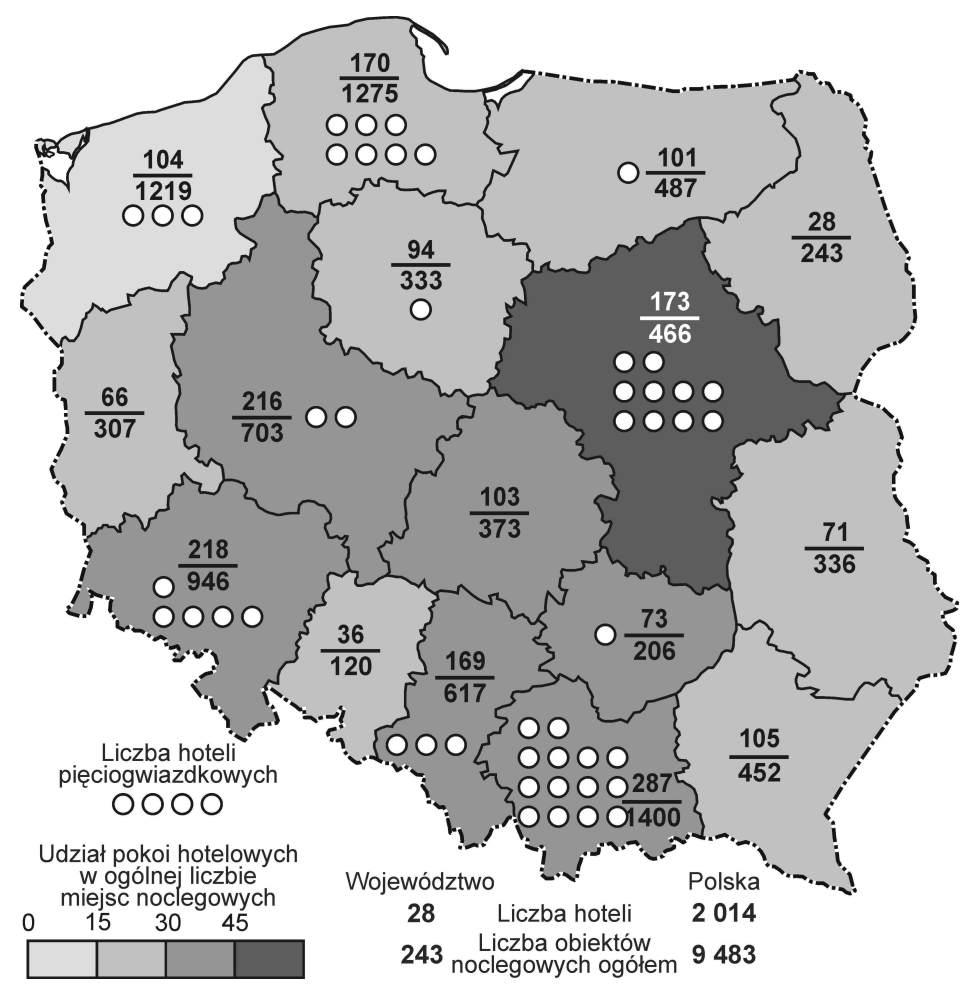

Rys. 7. Hotele na tle obiektów bazy noclegowej w Polsce w roku 2012 według województw Źródło: opracowanie własne na podstawie sprawozdawczości GUS (2013)

Dość zróżnicowany regionalnie w Polsce jest udział miejsc w hotelach w ogólnej liczbie miejsc noclegowych. Wartości tego wskaźnika wahają się od 12,1\% w przypadku województwa zachodniopomorskiego do 59,8\% w województwie mazowieckim. Tak wysoka wartość wskaźnika w tym ostatnim przypadku wynika m.in. $\mathrm{z}$ faktu znajdowania się na jego terenie miasta stołecznego, w którym zarejestrowano 64 hotele, a liczba miejsc noclegowych w województwie wynosi jedynie 45,7 tys. (tab. 4).

Wartość tego wskaźnika dla województwa łódzkiego wynosi 27,6\% w przypadku obiektów i 42,9\% odnośnie do liczby miejsc noclegowych w hotelach. Takie parametry sytuują region wyraźnie powyżej średniej dla 


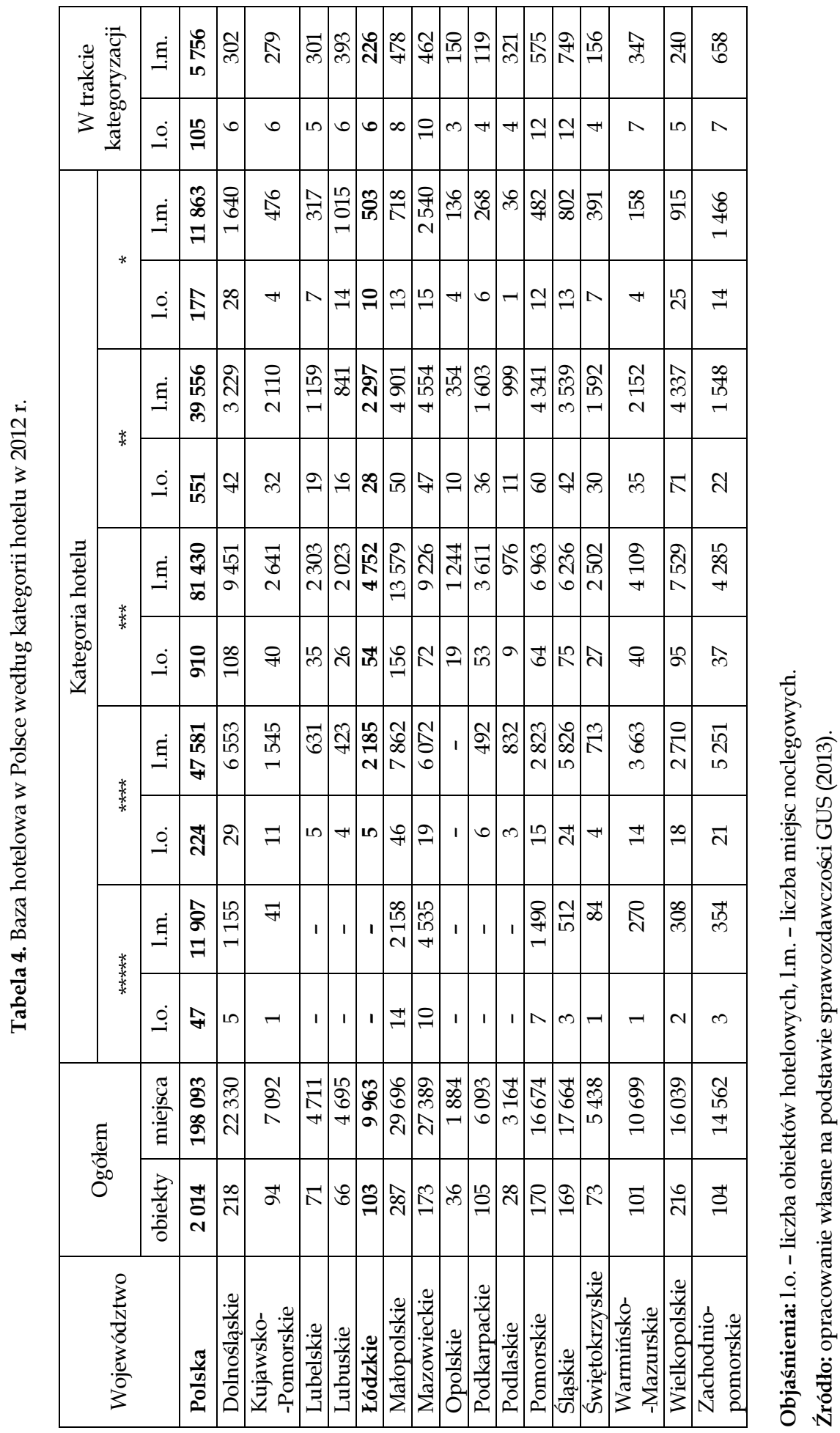


Polski, gdzie wymienione wskaźniki osiągają odpowiednio 21,2\% (obiekty) i 29,3\% (miejsca noclegowe).

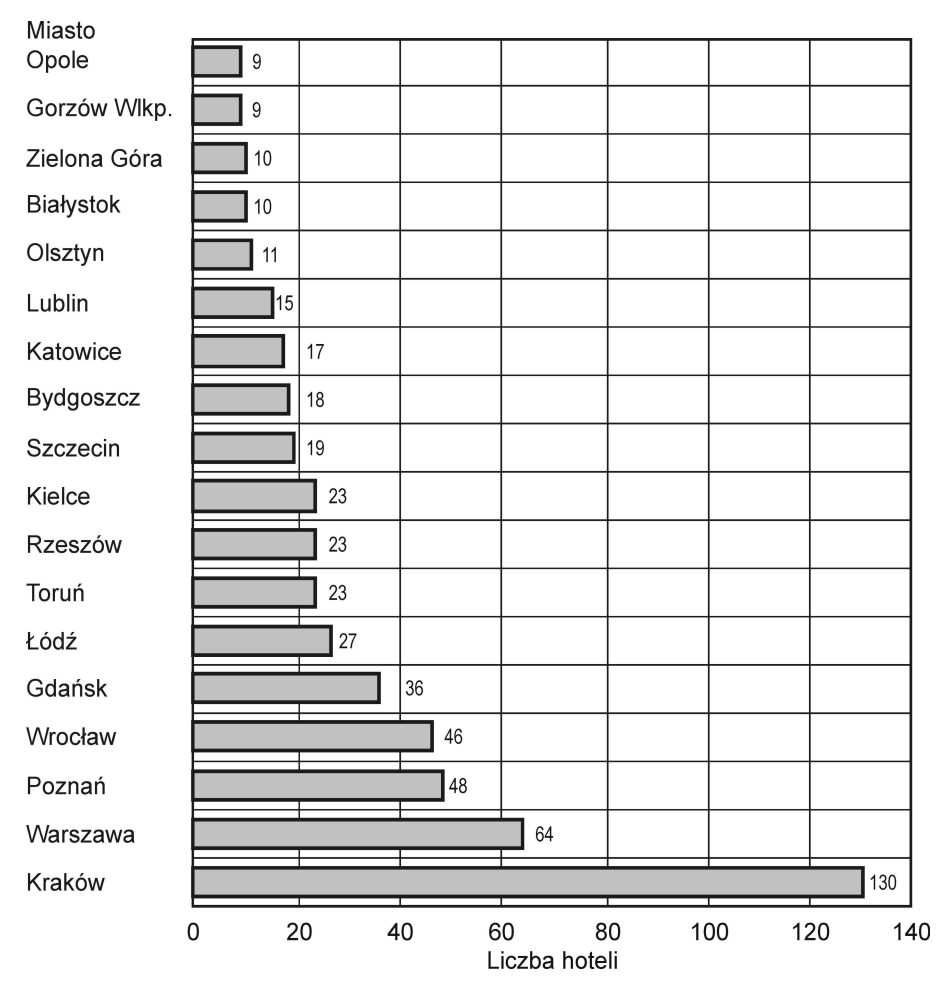

Rys. 8. Liczba hoteli w miastach wojewódzkich w roku 2012

Źródło: opracowanie własne na podstawie sprawozdawczości GUS (2013)

Wśród miast pełniących funkcje wojewódzkie zdecydowanym liderem, jeśli chodzi o liczbę hoteli, jest Kraków (130 obiektów). Nie jest to niczym zaskakującym, biorąc pod uwagę atrakcyjność turystyczną miasta, liczbę organizowanych wydarzeń kulturalnych, spotkań czy konferencji. Na drugim miejscu znalazła się stolica kraju, która może poszczycić jedynie 64 obiektami, co w stosunku do Krakowa jest wartością prawie dwukrotnie mniejszą. Odwrotnie przedstawia się jednak sytuacja w przypadku liczby miejsc hotelowych. Tu zdecydowanie dominuje Warszawa (19318 miejsc w hotelach), co wynika $\mathrm{z}$ wielkości obiektów zlokalizowanych $\mathrm{w}$ mieście stołecznym. Kraków, ze względu na bardziej kameralne obiekty, dysponuje potencjałem 
wielkości 17085 hotelowych miejsc noclegowych. Na kolejnych miejscach znalazły się Wrocław (46/7305), Poznań (48/5615) i Gdańsk (36/5068), w których liczba hoteli wynosi powyżej 35, a liczba miejsc noclegowych w tego rodzaju bazie przekroczyła 5000 .

Łódź, posiadająca w 2012 r. 27 hoteli (w roku 2014 były już 32 tego rodzaju obiekty), zajmowała szóste miejsce wśród miast pełniących funkcje wojewódzkie. Wartość ta plasowała miasto w grupie takich ośrodków wojewódzkich, jak Toruń, Rzeszów czy Kielce (rys. 8).

Najwyższym poziomem obłożenia pokoi hotelowych może poszczycić się Warszawa $(63,4 \%)$, co wynika zapewne z jej stołecznego charakteru i mniejszej sezonowości odwiedzin. Wskaźnik frekwencji powyżej 50\% osiągnęły jeszcze trzy atrakcyjne turystycznie miasta wojewódzkie, tj. Kraków (58,0\%), Gdańsk (51,4\%) oraz Wrocław (51,3\%).

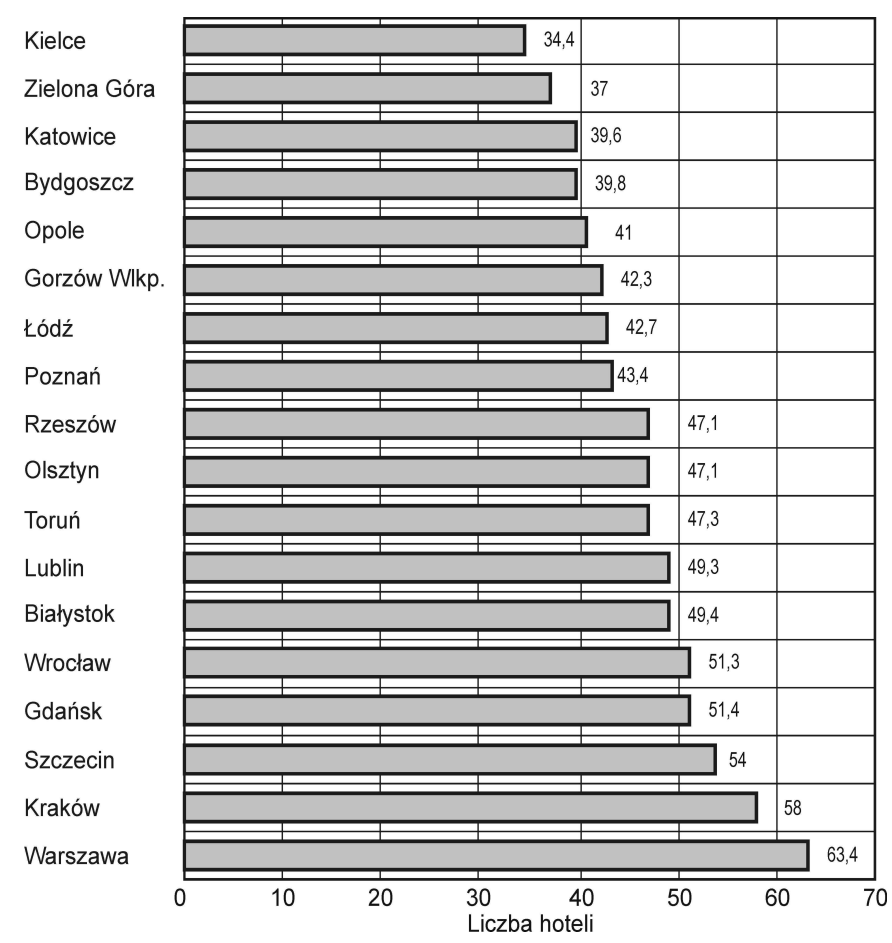

Rys. 9. Obłożenie pokoi hotelowych w miastach wojewódzkich w roku $2012(\mathrm{w} \%)$

Źródło: opracowanie własne na podstawie sprawozdawczości GUS (2013) 
W tym zestawieniu Łódź zajmuje dopiero 13. miejsce wśród ośrodków wojewódzkich. Wynika to prawdopodobnie $\mathrm{z}$ wyraźnie sezonowego charakteru ruchu turystycznego, zbyt krótkich odwiedzin niewymagających zatrzymywania się $w$ hotelu, oraz korzystania przez odwiedzających $\mathrm{z}$ bazy noclegowej położonej poza miastem, w tym w nieodległej Warszawie (rys. 9).

\section{Baza noclegowa w województwie łódzkim}

Historia rozwoju hotelarstwa w regionie łódzkim nie odbiega zasadniczo od innych obszarów kraju (MILEWSKA, WŁODARCZYK 2005), jedynie Łódź nieco "odstaje" od schematu rozwoju historycznego bazy noclegowej. Stolica regionu, jako dynamicznie rozwijające się miasto przemysłowe, w odróżnieniu od innych wielkich miast o rodowodzie średniowiecznym, swoją bazę hotelarską ukształtowała dopiero w drugiej połowie XIX w. (MILEWSKA, WŁODARCZYK 2004).

Ostatnie lata w rozwoju hotelarstwa w województwie łódzkim są poniekąd odzwierciedleniem globalnego kryzysu gospodarczego, który przejawiał się m.in. zahamowaniem wzrostu, a nawet niewielkim spadkiem liczby obiektów (lata 2007-2008), ale nie spowodował zmniejszenia wzrostu liczby miejsc noclegowych (rys. 10 i 11).

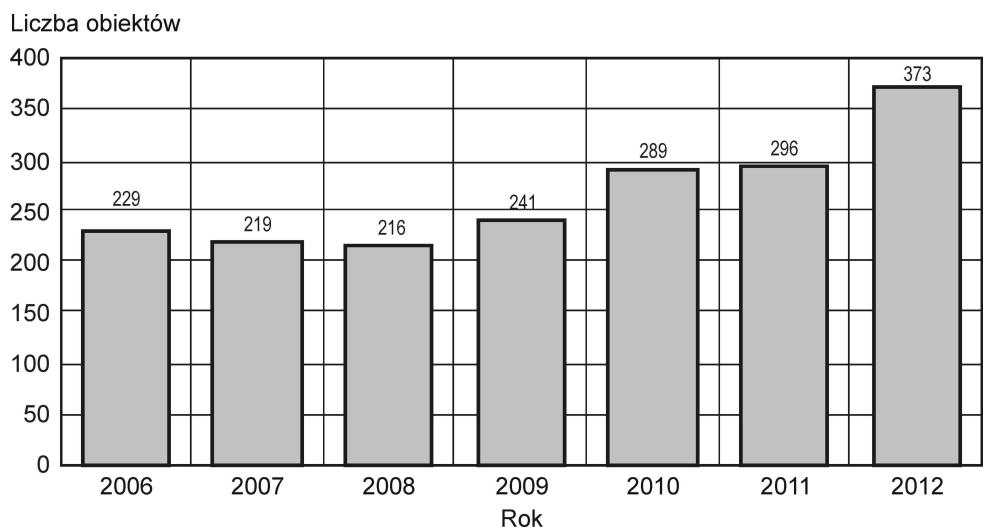

Rys. 10. Obiekty noclegowe w województwie łódzkim w latach 2006-2012 Źródło: opracowanie autora na podstawie danych Urzędu Statystycznego w Łodzi (2007-2013) 
W tym czasie w Łodzi kontynuowane były rozpoczęte inwestycje hotelowe, można więc zaryzykować stwierdzenie, że region dość łagodnie przeszedł przez okres załamania koniunktury na rynku hotelarskim. Lata 2009 -2011, które w turystyce światowej były nadal okresem zastoju inwestycji, w regionie łódzkim zaznaczyły się wzrostem omawianych parametrów. Widoczne na rys. 10 i 11 wyraźne zwiększenie się liczby obiektów i miejsc noclegowych w roku 2012 nie jest jednak tylko wynikiem poprawy sytuacji na rynku hotelarskim, ale $\mathrm{w}$ dużej mierze efektem nowego sposobu rejestracji bazy noclegowej przez GUS. Od tego roku bowiem GUS zaczął publikować dane uzupełnione o pokoje gościnne i kwatery agroturystyczne, które, pomimo niewielkiego udziału w województwie łódzkim w stosunku do innych regionów kraju, zdecydowanie zaznaczają się w przypadku liczby obiektów, a ze względu na niewielkie rozmiary w mniejszym stopniu na liczbę miejsc noclegowych (rys. 10 i 11).

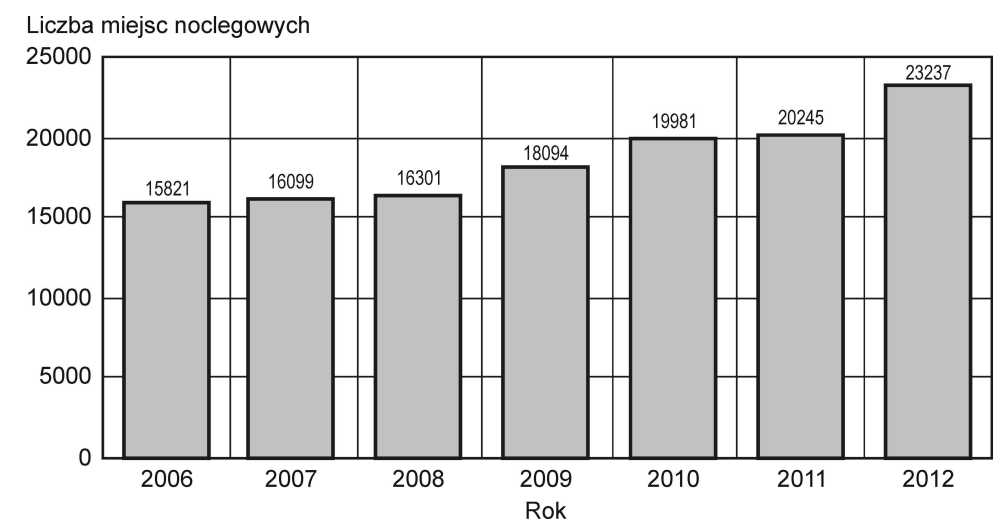

Rys. 11. Liczba miejsc noclegowych w województwie łódzkim w latach 2006-2012 Źródło: opracowanie autora na podstawie danych Urzędu Statystycznego w Łodzi (2007-2013)

Opisaną wcześniej sytuację potwierdza struktura bazy noclegowej (rys. 12), gdzie wyraźnie widać większy udział obiektów zakwaterowania indywidualnego (13,1\%) w stosunku do liczby miejsc noclegowych (3,5\%) rejestrowanych w tej samej kategorii. Pozytywnym zjawiskiem jest znaczący udział obiektów o standardzie hotelowym, który przekracza 50\% zarówno pod względem liczby obiektów, jak i miejsc noclegowych. Tylko hotele, a więc obiekty podlegające najbardziej surowym przepisom kategoryzacyjnym, stanowią 27,6\% obiektów i dysponują 43,2\% miejsc noclegowych. 

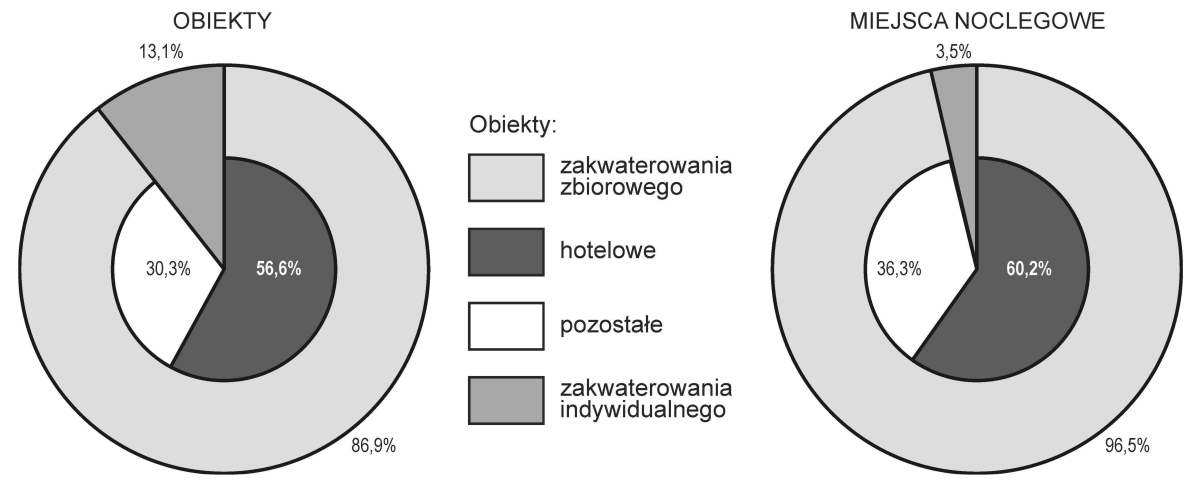

Rys. 12. Struktura bazy noclegowej w województwie łódzkim w 2012 r. według rodzaju obiektu Źródło: Urząd Statystyczny w Łodzi

Tabela 5. Baza noclegowa województwa łódzkiego według powiatów w roku 2012

\begin{tabular}{|c|c|c|c|c|c|c|c|}
\hline \multirow{3}{*}{ Lp. } & \multirow{3}{*}{ Powiat } & \multirow{2}{*}{\multicolumn{2}{|c|}{$\begin{array}{l}\text { Obiekty noclegowe } \\
\text { ogółem }\end{array}$}} & \multicolumn{4}{|c|}{ Miejsca noclegowe } \\
\hline & & & & \multicolumn{2}{|c|}{ ogółem } & \multicolumn{2}{|c|}{ w tym całoroczne } \\
\hline & & liczba & odsetek & liczba & odsetek & liczba & odsetek \\
\hline 1. & bełchatowski & 20 & 5,4 & 1612 & 6,9 & 1296 & 80,4 \\
\hline 2. & brzeziński & 7 & 1,9 & 178 & 0,8 & 178 & 100,0 \\
\hline 3. & kutnowski & 17 & 4,5 & 432 & 1,9 & 432 & 100,0 \\
\hline 4. & Łódź & 68 & 18,3 & 6544 & 28,2 & 6481 & 99,0 \\
\hline 5. & łódzki wschodni & 16 & 4,3 & 716 & 3,1 & 540 & 75,4 \\
\hline 6. & laski & 8 & 2,1 & 408 & 1,8 & 288 & 70,6 \\
\hline 7. & łęczycki & 4 & 1,1 & 74 & 0,3 & 74 & 100,0 \\
\hline 8. & łowicki & 14 & 3,7 & 533 & 2,3 & 481 & 90,2 \\
\hline 9. & opoczyński & 7 & 1,9 & 150 & 0,6 & 150 & 100,0 \\
\hline 10. & Piotrków Trybunalski & 13 & 3,5 & 817 & 3,5 & 450 & 55,1 \\
\hline 11. & pabianicki & 18 & 4,8 & 737 & 3,2 & 660 & 89,6 \\
\hline 12. & pajęczański & 5 & 1,4 & 157 & 0,7 & 157 & 100,0 \\
\hline 13. & piotrkowski & 22 & 5,9 & 1820 & 7,8 & 1138 & 62,5 \\
\hline 14. & poddębicki & 16 & 4,3 & 468 & 2,0 & 323 & 69,0 \\
\hline 15. & radomszczański & 12 & 3,2 & 437 & 1,9 & 437 & 100,0 \\
\hline 16. & rawski & 8 & 2,1 & 1436 & 6,2 & 1436 & 100,0 \\
\hline 17. & Skierniewice & 3 & 0,8 & 96 & 0,4 & 96 & 100,0 \\
\hline 18. & skierniewicki & 2 & 0,5 & 106 & 0,5 & 0 & 0,0 \\
\hline 19. & sieradzki & 9 & 2,4 & 387 & 1,7 & 325 & 84,0 \\
\hline 20. & tomaszowski & 33 & 8,8 & 2569 & 11,0 & 1957 & 76,2 \\
\hline 21. & wieluński & 22 & 5,9 & 1137 & 4,9 & 792 & 69,7 \\
\hline 22. & wieruszowski & 9 & 2,4 & 266 & 1,1 & 138 & 51,9 \\
\hline 23. & zduńskowolski & 12 & 3,2 & 543 & 2,3 & 393 & 72,4 \\
\hline 24. & zgierski & 28 & 7,6 & 1614 & 6,9 & 1210 & 75,0 \\
\hline \multicolumn{2}{|c|}{ Województwo } & 373 & 100,0 & 23237 & 100,0 & 19432 & $X$ \\
\hline
\end{tabular}

Źródło: opracowanie autora na podstawie danych Urzędu Statystycznego w Łodzi (2013). 
Pomijając Łódź, która nie ma porównywalnej konkurencji w regionie, w województwie wyróżnia się powiat tomaszowski zarówno pod względem liczby obiektów, jak i liczby miejsc noclegowych oraz zróżnicowanej struktury bazy (tab. 5 i 6). Spowodowane jest to ponadprzeciętnymi walorami turystycznymi regionu (Spała, Zalew Sulejowski, rzeka Pilica), a także długimi tradycjami rozwoju funkcji turystycznej. Do powiatów o lepiej rozwiniętej bazie noclegowej (rys. 13) zaliczyć można ponadto piotrkowski (dolina Pilicy), bełchatowski (duże powierzchnie leśne), wieluński (dolina Warty) oraz zgierski (strefa krawędziowa Wyżyny Łódzkiej) i kutnowski (położenie tranzytowe).

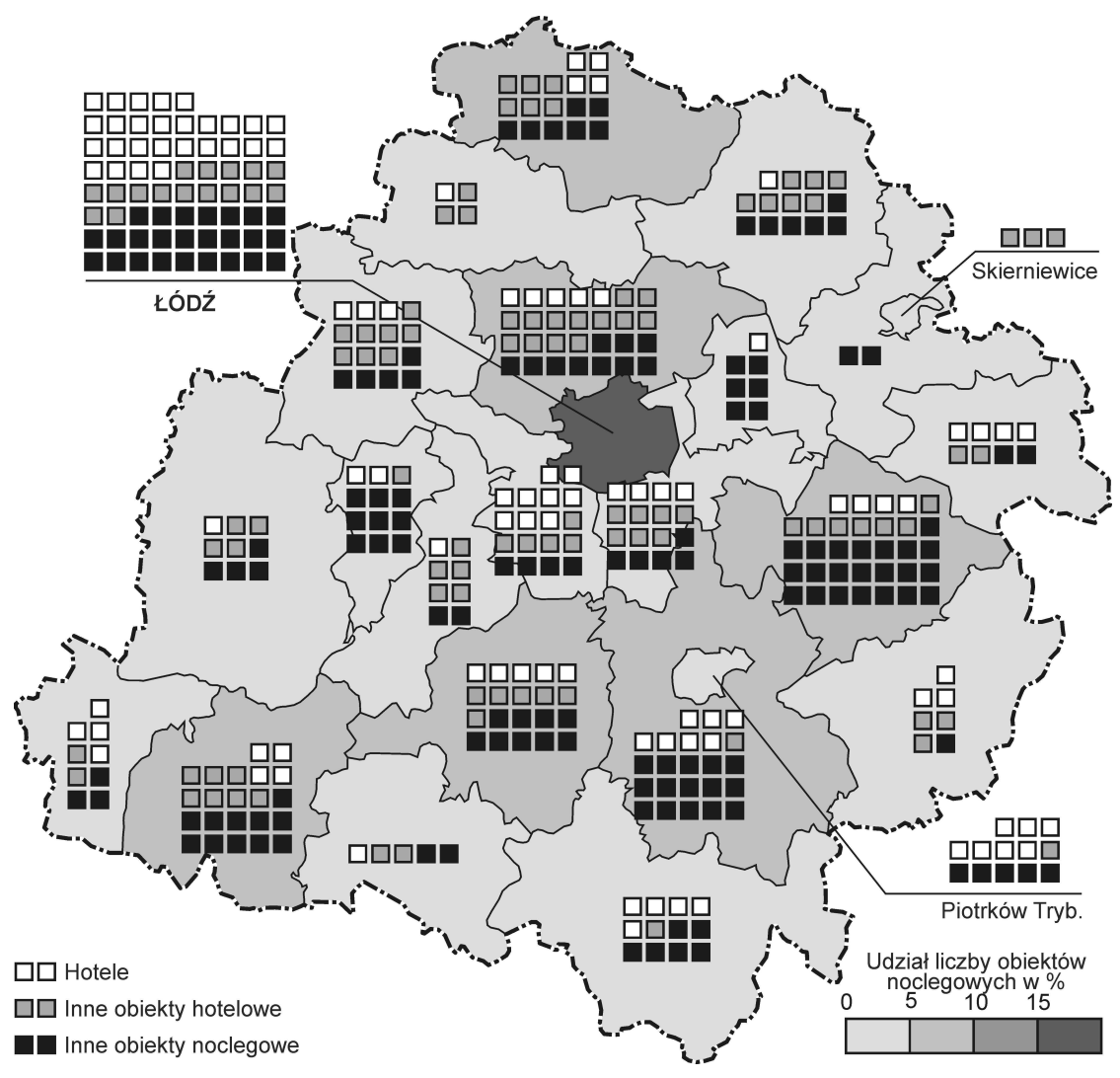

Rys. 13. Obiekty noclegowe w województwie łódzkim według powiatów w 2012 r.

Źródło: opracowanie autora na podstawie danych Urzędu Statystycznego w Łodzi (2013) 


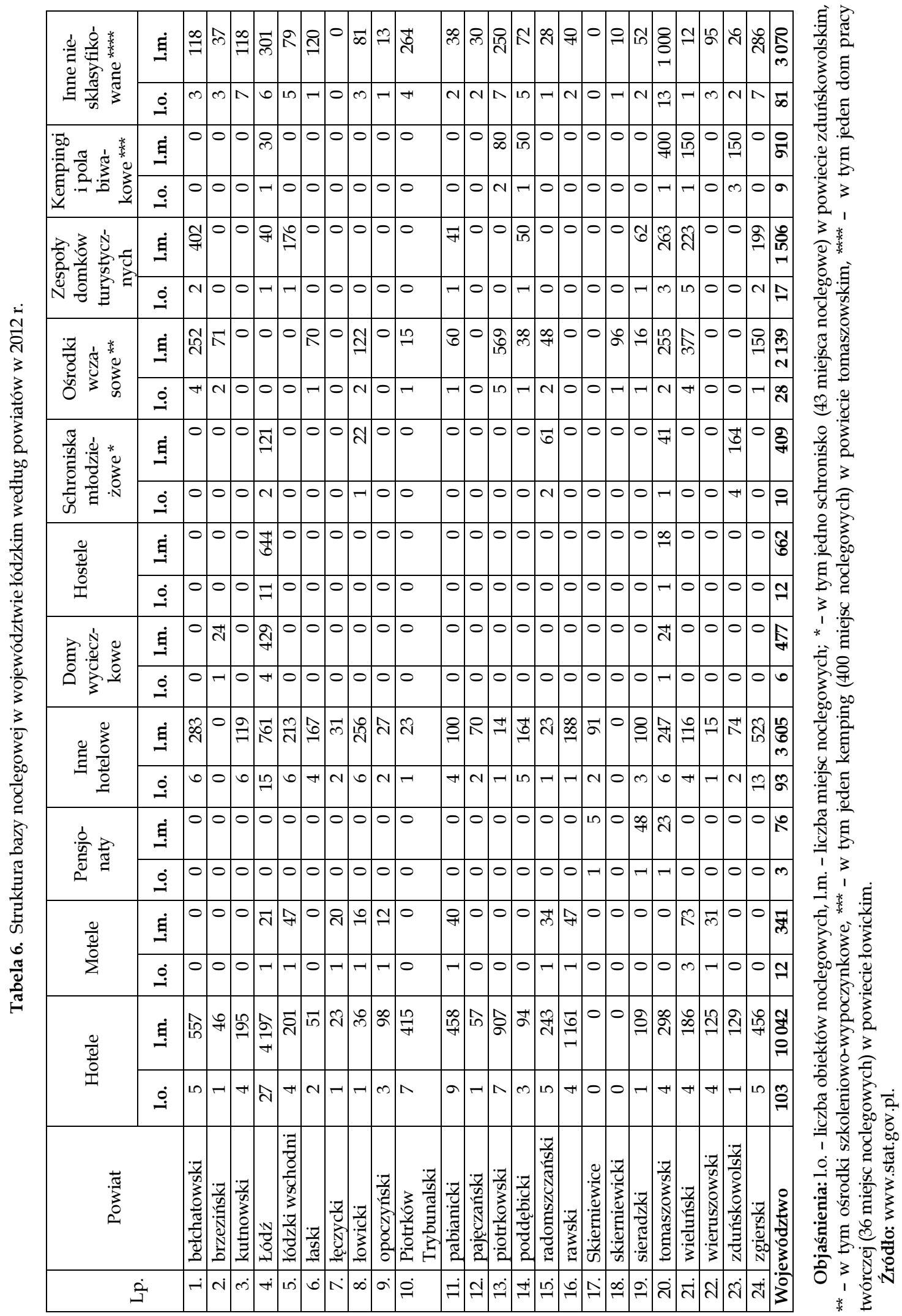


Na rys. 13 można zauważyć jeszcze pewną prawidłowość związaną z koncentracją obiektów typu hotelowego w strefie podmiejskiej Łodzi (m.in. powiaty zgierski, pabianicki i łódzki wschodni).

Analizując liczbę miejsc noclegowych, do grupy powiatów o rozwiniętej funkcji noclegowej zaliczyć jeszcze należy powiat rawski (ze względu na lokalizację dużego centrum kongresowo-konferencyjnego) oraz poddębicki (rozwijający bazę noclegową związaną z wykorzystaniem wód geotermalnych) (rys. 14).

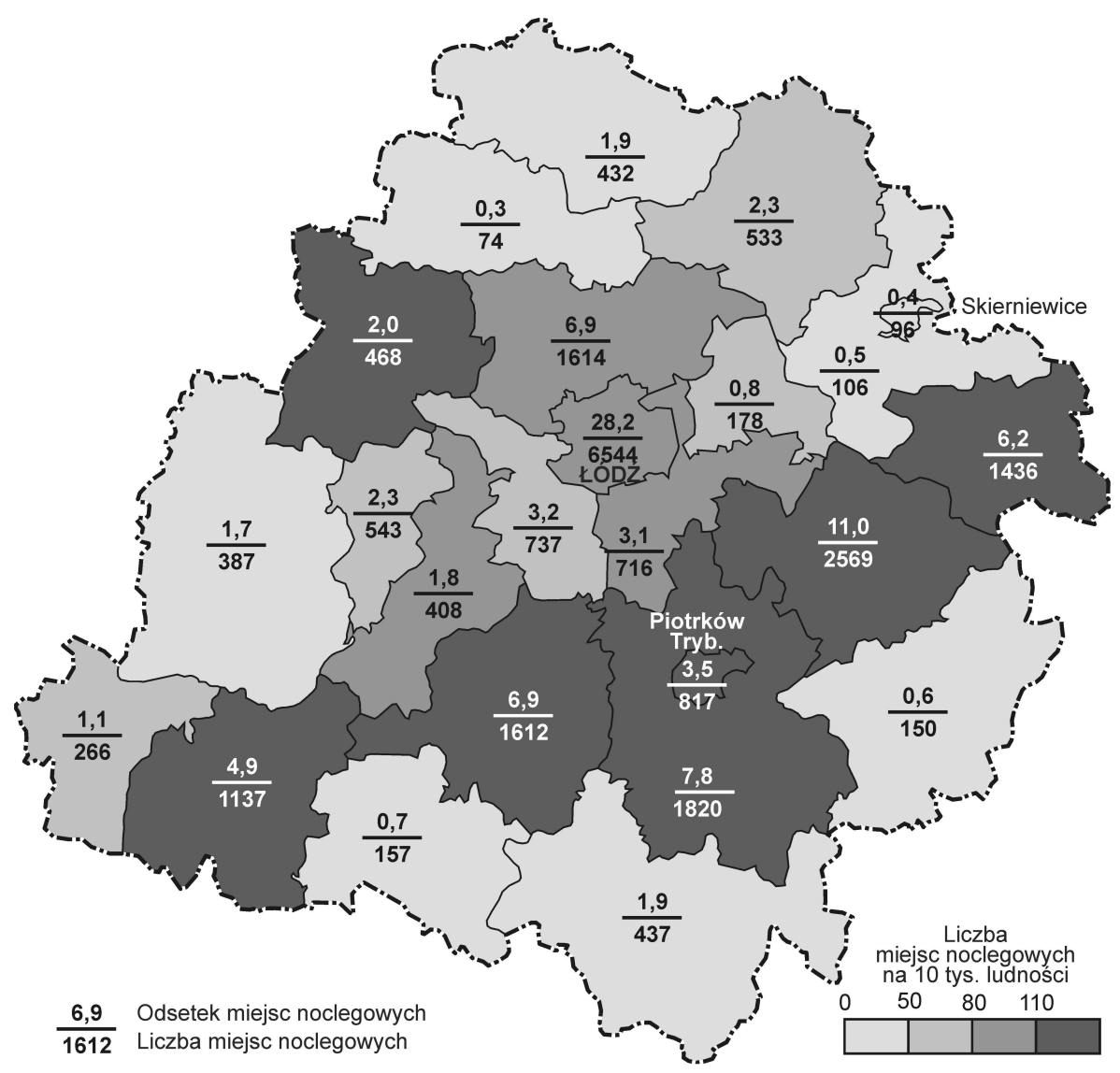

Rys. 14. Liczba miejsc noclegowych w powiatach województwa łódzkiego w 2012 r.

Źródło: opracowanie autora na podstawie danych Urzędu Statystycznego w Łodzi (2013) 
Najwyższy stopień nasycenia miejscami noclegowymi na 10 tys. ludności (powyżej 110 miejsc noclegowych) wyróżnia wymienione wcześniej powiaty tworzace charakterystyczny pas na południe od strefy podmiejskiej Łodzi (SW-NE) oraz powiat poddębicki. Kolejną strefę o dość wysokim poziomie tego wskaźnika tworzą powiaty zaliczane do obszaru metropolitalnego Łodzi (od 80 do 110 miejsc noclegowych).

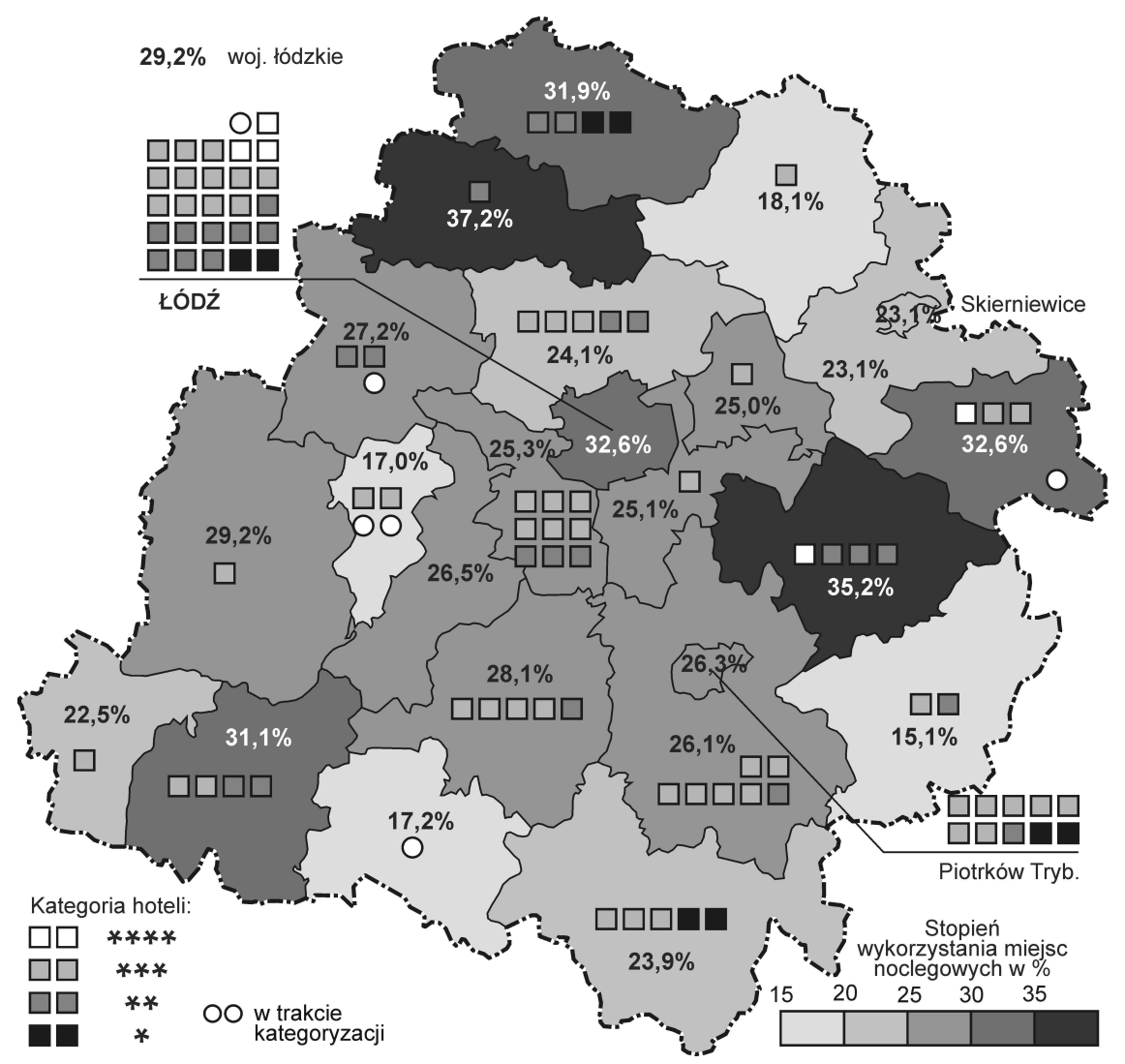

Rys. 15. Stopień wykorzystania miejsc noclegowych w województwie łódzkim w 2012 r. według powiatów

Źródło: opracowanie autora na podstawie danych Urzędu Statystycznego w Łodzi

Struktura bazy noclegowej w województwie łódzkim (tab. 6) nie jest zbyt zróżnicowana. Oprócz wspomnianych hoteli w strukturze zaznaczają się jeszcze inne obiekty hotelowe (93 obiektów, 3605 miejsc noclegowych) oraz 
inne obiekty niesklasyfikowane (81 obiektów, 3070 miejsc noclegowych). W regionie łódzkim w 2012 r. funkcjonowało jeszcze 12 moteli oraz jedynie trzy pensjonaty. Hostele i schroniska młodzieżowe, a więc tania baza noclegowa adresowana do mniej zamożnych turystów, stanowiły w 2012 r. 22 obiekty $(5,9 \%)$, które oferowały 1071 miejsc noclegowych (4,6\%). W całym województwie w roku 2012 zarejestrowano tylko jeden kemping (powiat tomaszowski), dysponujący infrastrukturą mogącą obsłużyć 400 gości. Bazę wakacyjno-urlopową oraz szkoleniowo-wypoczynkową tworzyło 45 obiektów (3645 miejsc noclegowych), co stanowiło odpowiednio 12,1\% obiektów i $15,7 \%$ miejsc noclegowych.

Wśród obiektów noclegowych dominowały hotele (103 obiekty, 10042 miejsc noclegowych), przy czym najliczniejszą grupę stanowiły obiekty trzygwiazdkowe, których w 2012 r. było w regionie 54, co stanowiło 52,4\% wszystkich hoteli. Drugą pod względem liczebności tworzyły hotele dwugwiazdkowe - 28 (27,2\%). W tym okresie w regionie funkcjonowało jeszcze pięć hoteli czterogwiazdkowych oraz siedem jednogwiazdkowych. Pozostałe obiekty były w trakcie kategoryzacji (rys. 15). Jak już wspomniano, w regionie nie było ani jednego hotelu pięciogwiazdkowego.

Wysoce niezadowalający jest stopień wykorzystania (obłożenia) bazy noclegowej, który dla całego regionu $(29,2 \%$ ) nie przekracza nawet $30 \%$ (rys. 15). Jedynie dwa powiaty przekraczają granicę 35-procentowej frekwencji $\mathrm{w}$ bazie noclegowej. Jest to wielokrotnie wymieniany już powiat tomaszowski $(35,2 \%)$ oraz łęczycki, który ze swoimi czterema obiektami hotelowymi osiągnął wartość tego wskaźnika na poziomie 37,2\%. Wartości te zaniżają prawdopodobnie obiekty sezonowe i niesklasyfikowane, bowiem frekwencja liczona jedynie dla obiektów hotelowych w 2012 r. przekraczała zazwyczaj $40 \%$, w sezonie wysokiego obłożenia nierzadko $50 \%$.

\section{Podsumowanie}

Województwo łódzkie w stosunku do znaczących walorów turystycznych oraz potencjału gospodarczego (turystyka biznesowa) posiada bazę noclegową zdecydowanie zbyt skromną zarówno pod względem liczby obiektów, jak i liczby miejsc noclegowych. Analizując różnego rodzaju parametry i wskaźniki można stwierdzić, że łódzkie zamyka pierwszą dziesiątkę regio- 
nów, co w przypadku 16 województw w kraju jest pozycją wysoce niezadowalającą.

Stolica województwa, pomimo dużego potencjału turystycznego, gospodarczego i biznesowego pod względem wielkości i struktury bazy noclegowej wyraźnie wyróżnia się na niekorzyść od innych porównywalnych pod względem potencjału ludnościowego, ośrodków miejskich w Polsce.

Region nie dysponuje ani jednym hotelem najwyższej kategorii (pięć gwiazdek), a jedynie pięcioma hotelami czterogwiazdkowymi, co sprawia, że część zamożnych gości wybiera na nocleg miejscowości położone w innych regionach. Budowa jedynego planowanego w Łodzi obiektu pięciogwiazdkowego znanej światowej marki została zarzucona w wyniku kryzysu w branży. W przypadku luksusowych usług hotelarskich największą konkurencją dla regionu i jego stolicy, biorąc pod uwagę bardzo dobrą komunikację (autostrada A-2), są hotele warszawskie.

Hotelarstwo w regionie łódzkim oparło się niekorzystnym tendencjom związanym z globalnym kryzysem gospodarczym, który dotknął także branżę turystyczną, w tym najdotkliwiej sektor hotelarski. Jednak mając na uwadze niskie wskaźniki wykorzystania pokoi i miejsc noclegowych, rzadko przekraczających poziom 30\%, dyskusyjne wydają się być kolejne inwestycje w obiekty bazy noclegowej.

\section{BIBLIOGRAFIA}

KACZMAREK J., STASIAK A., WŁODARCZYK B., 2010, Produkt turystyczny, PWE, Warszawa, ss. 447.

KOWALCZYK A., DEREK M., 2010, Zagospodarowanie turystyczne, Wyd. Naukowe PWN, Warszawa, ss. 400.

KOWALCZYK A., 2001, Geografia hotelarstwa, Wyd. Uniwersytetu Łódzkiego, Łódź, ss. 429.

MATCZAK A., (red.) 2004, Lokalizacja hoteli w krajowych metropoliach Europy Środkowo-Wschodniej, „Śladami Nauki" 33, Łódzkie Towarzystwo Naukowe, Łódź, ss. 129.

MILEWSKA M., SKRZYPCZYŃSKI M., WŁODARCZYK B., 2004, Mierniki jako ważny element nauczania hotelarstwa, „Turystyka i Hotelarstwo" 5, s. 107-133.

MiLEWSKA M., WŁODARCZYK B., 2004, Historia hotelarstwa w Łodzi, „Turystyka i Hotelarstwo" 5, s. 55-94.

MiLEWSKA M., WŁODARCZYK B., 2005, Historia i stan obecny hotelarstwa w regionie łódzkim, „Turystyka i Hotelarstwo" 7, s. 133-166.

MiLEWSKA M., WŁODARCZYK B., 2009, Hotelarstwo. Podstawowe wiadomości, Polskie Wydawnictwo Ekonomiczne, Warszawa, ss. 386.

Turystyka w 2012 r., 2013, „Informacje i Opracowania Statystyczne”, Główny Urząd Statystyczny, Urząd Statystyczny w Rzeszowie, Warszawa.

Turystyka w województwie tódzkim w 2012 r. Informacja sygnalna, 2013, Urząd Statystyczny w Łodzi, Łódź.

Województwo tódzkie - podregiony, powiaty, gminy, 2007-2013, Urząd Statystyczny w Łodzi, Łódź. 


\section{HOSPITALITY IN ŁÓDŹ AND THE ŁÓDŹ REGION AT THE BEGINNING OF THE SECOND DECADE OF XXIST CENTURY}

Key words: Łódź region, tourism infrastructure, accommodation, hospitality, hotels

\section{Summary}

The accomodation in Lodz Voivodeship in refernce to its significant tourist resources as well as economic potential (business tourism) is not sufficient, both - analyzing the number of tourist accommodation establishments and number of bed places as well.

Providing the analyzis of varoius factors and indicators Lodz Voivodeship closes the top ten of the 16th polish voivodeships, which is highly insufficient. In 2012, in the region existed 373 tourist accommodation establishents, providing 23237 bed places. Hotels constituted over a third of the accomodation (103 accommodation establishments/9963 bed places).

Lodz as the capital of the vivodeship, despite remarkable tourism, economic and business potential, while analyzing the structure of accommodation stands out from other comparable in population city centers in Poland.

Although hospitality in the region overcame unfavorable trends associated with global economic crisis, which afflicted also tourism-related industries (especially hospitality), it seems controversial to invest in accommodation - the rate of use of bed places is hardly over $30 \%$. 